\title{
The relationship between health literacy and quality of life: a systematic review and meta-analysis
}

\author{
Mengyun Zheng ${ }^{1,2}$, Hui Jin ${ }^{1,2^{*}}$ (D), Naiyang Shi ${ }^{1}$, Chunxiao Duan ${ }^{1}$, Donglei Wang ${ }^{1}$, Xiaoge $\mathrm{Yu}^{1}$ and Xiaoning $\mathrm{Li}^{3}$
}

\begin{abstract}
Background: Low health literacy often has an association with poor health outcomes such as low levels of self-efficacy, increased mortality, poor health status and reduced quality of life (QOL). The aim of the study was to quantitatively evaluate the relationship between health literacy $(\mathrm{HL})$ and $\mathrm{QOL}$ based on a systematic review and meta-analysis.

Methods: EMBASE, PubMed, Web of Science, Elsevier, Cochrane Library, and Chinese electronic databases such as CNKI, and Wanfang were searched from 1970 until February 1, 2018. The pooled correlation coefficient (PCOR) and its 95\% confidence interval (Cl) between $\mathrm{HL}$ and $\mathrm{QOL}$ were estimated using R software. Potential sources of heterogeneity were explored using subgroup analysis, sensitivity analysis, and meta-regression.

Results: Twenty-three studies, with a total of 12,303 subjects,were included. The PCOR between HL and QOL was 0.35 (95\%Cl: 0.25-0.44). Considering different dimensions of HL, the PCOR between QOL and health knowledge, health behavior, health belief, and health skill were 0.36 ( $95 \% \mathrm{Cl}: 0.04-0.61), 0.36$ (95\%Cl: $0.13-0.55), 0.39$ (95\%Cl: 0.10-0.62), and 0.42 (95\%Cl: 0.03-0.69), respectively. The PCOR between $\mathrm{HL}$ and the two dimensions of QOL was lower than the total PCOR between HL and QOL. In subgroup analysis, the PCOR between HL and QOL was $0.46(95 \% \mathrm{Cl}: 0.13,0.69)$ among community residents, 0.45 (95\%Cl: $0.27,0.61)$ in China, and 0.45 (95\%Cl: $0.24,0.62)$ based on cohort studies. Sensitivity analyses showed that the stability of results had no significant after excluding the study $(p<0.001)$. Meta-regression showed that cohort study design, studies conducted in China, and publication before 2012 may be important influencing factors.
\end{abstract}

Conclusions: Health literacy was moderately correlated with quality of life, but this finding needs to be supported by more evidence.

Keywords: Health literacy, Quality of life, Correlation coefficient, Systematic review, Meta-analysis

\section{Background}

Quality of life (QOL) refers to how individuals subjectively assess their own well-being and their ability to perform physical, psychological, and social functions [1]. As an indicator of health and living standards, the concept and connotations of QOL were defined in multiple ways because of different research objectives and purpose, QOL is a multidimensional concept that can fully reflect

\footnotetext{
* Correspondence: jinhui_hld@163.com

${ }^{1}$ Department of Epidemiology and Health Statistics, School of Public Health, Southeast University, Nanjing 210009, China

${ }^{2}$ Key Laboratory of Environmental Medicine Engineering, Ministry of

Education, School of Public Health, Southeast University, Nanjing 210009,

China

Full list of author information is available at the end of the article
}

person's overall health situation by measuring four dimensions: physical health, physiological health, social health, and mental health. Nowadays, QOL is viewed as a significant outcome of health care and has been increasingly used as a comprehensive health indicator in medical interventions and population health surveys [2]. QOL is mainly used in evaluation of health status and health resources and used as an aspect of influencing factors and health intervention measures, which have higher stability and sensitivity [3].

Health literacy (HL) is linked to literacy and entails people's knowledge, motivation and competence to access, understand, appraise, and apply health information to make judgments and take decisions in everyday life

(c) The Author(s). 2018 Open Access This article is distributed under the terms of the Creative Commons Attribution 4.0 International License (http://creativecommons.org/licenses/by/4.0/, which permits unrestricted use, distribution, and reproduction in any medium, provided you give appropriate credit to the original author(s) and the source, provide a link to the Creative Commons license, and indicate if changes were made. The Creative Commons Public Domain Dedication waiver (http://creativecommons.org/publicdomain/zero/1.0/) applies to the data made available in this article, unless otherwise stated. 
concerning healthcare, disease prevention and health promotion to maintain or improve QOL during the course of life [4].

At present, the United States, Canada, Australia, and China have all conducted national HL surveys and Europe participated in a comparative European health literacy survey. The survey in Europe showed that there was lack of HL about $47.6 \%$ of the study population [5]. In Canada the figure was about 60\% [6] and in Australia it was 21\% [7], while only $12 \%$ in the United States [8], and $9.48 \%$ in China had good HL [9]. HL is becoming an important determinant of life expectancy and might also affect QOL.

Many studies [10-15] have investigated the relationship between HL and QOL, but the results seemed inconsistent. Some studies showed that QOL had a positive association with $\mathrm{HL}$, while other studies showed that QOL had a negative association with HL $[10,16]$. In China, HL was divided into four dimensions and each was compared QOL: health knowledge, health belief, health behavior and health skill [17-19]. Similarly, the surveys of HL abroad were divided into different levels; QOL differed depending on how high or low the levels of HL were [20-22]. The differences in these results, the survey dimensions of $\mathrm{HL}$ and QOL, and the differences in the questionnaires potentially lead to be inconsistent conclusions. Therefore, the aim of this study was to provide a complete overview of the literature regarding the direct impact of HL on QOL, and to discuss the correlation between HL and two dimensions of QOL and the correlation between QOL and four dimensions of $\mathrm{HL}$ based on a systematic review and meta- analysis.

\section{Methods}

This systematic review followed the PRISMA (Preferred Reporting Items for Systematic Reviews and Meta-Analyses) guidelines [23] (Additional file 1: Table S1).

We searched English and Chinese language publications on EMBASE, PubMed, Web of Science, Elsevier, Cochrane Library, and Chinese databases such as CNKI and Wanfang from 1970 to February 1, 2018. Studies were searched using logical terms, and search strategy is as follows: "\#1 health literacy," "\#2 literacy," "\#3 numeracy"; “\#5 quality of life," "\#6 life quality," "\#7 health-related quality of life," “\#8 QOL," “\#9 HRQOL," “\#10 life style." \# 4 is “\#1 OR \#2 OR \#3", \# 11 is “\#5 OR \#6 OR \#7 OR \#8 OR \#9 OR \#10", and \# 12 is "\#4 AND \#11" finally. Medical subject headings $(\mathrm{MeSH})$ and wild-card options were used where appropriate. Meanwhile, the bibliographies of original studies and reviews were manually searched.

Studies that met the following criteria were included: [1] the study subjects were human, [2] the levels of HL and QOL were conducted and compared as the key objective, [3] the outcome was the correlation coefficient between
HL and QOL, and [4] original articles published in English or Chinese (no posters abstracts, letters to the editor etc.).

Studies were excluded for the following reasons: [1] case reports or review articles, [2] QOL or HL was not measured or was not a part of a validated questionnaire, [3] articles were not published in peer-reviewed journals, and [4] there was no the correlation coefficient between HL and QOL. For studies that had been repeated, only the most recent and detailed studies were included in the analysis.

In some studies, there were only QOL scores at different levels of HL without the correlation coefficient between HL and QOL, and there were also some studies with the correlation coefficient compared with the reference materials. These controversial articles are excluded from meta-analysis through discussion.

Two authors independently extracted the following data from the selected studies: the first author, year of publication, design, survey time, location, study population, QOL instrument, and HL instrument. The quality of each of the included studies was independently assessed by two investigators using the Newcastle-Ottawa Scale (NOS) [24] or Agency for Healthcare Research and Quality (AHRQ) [25]. The quality of cross-sectional studies was assessed using AHRQ, and cohort studies were assessed using NOS. The NOS scale has 8 items, and the highest possible total score is 9 . The quality of the study is indicated by the scores: 0-5 indicates low quality, 6-7 indicates medium quality, and 8-9 indicates high quality [26]. The AHRQ scale has 11 items, all of which are rated as "yes" (1 point), "no" or "unclear" (0 point), and the highest possible total score is 11 . The quality of the study is indicated by the scores: $0-3$ indicates low quality, $4-7$ indicates medium quality, and 8-11 indicates high quality [27].

\section{Statistical analysis}

Different results indicated effects of different sizes regarding the relationship between HL and QOL. Summary statistics were then calculated. Most meta-analysis did not directly use the values of each correlation coefficients when combined correlation coefficients, because the variance of each correlation coefficient was too dependent on the correlation. Thus, we needed to convert various data into correlation coefficient uniformly, for which meta-analysis was performed. The method we used was to carry out the correlation coefficient ( $r$ value) of each study by Fisher's $\mathrm{Z}$ transformation, calculate the standard error, and calculate the summary Fisher's $\mathrm{Z}$ value using the inverse variance. Then a formula was used to transform the $\mathrm{Z}$ value into an $\mathrm{r}$ value [28].

To calculate the summary or pooled $r$, and $95 \% \mathrm{CI}$, the hypothesis test was used to judge whether the correlation was statistically significant. Lastly, a forest plot was used 
to indicate the effect size. Publication bias was assessed by funnel plots and the Egger's test.

$R$ software $(R \times 64 \quad 3.4 .1)$ was used for meta-analysis. Firstly, it estimated heterogeneity between studies using $Q$ and $I^{2}$ statistics. According to the Q-statistic, if the $p<0.05$ and $I^{2}<50 \%$, it indicated heterogeneity in the risk factors between studies, and the random effect model was used for the meta-analysis. Otherwise, the fixed effect model was used.

In addition, subgroup analysis, sensitivity analysis and meta-regression analysis were conducted through $\mathrm{R}$ software. A sensitivity analysis was performed to ensure the stability of the results. Meta-regression analyses were conducted to assess heterogeneity; it can also be used to analyze the differences of categorical explanatory variables introduced in subgroup analysis. The dependent variable of meta-regression is the correlation coefficient between HL and QOL, and the research sample, research type, research population, area, time, research quality and questionnaire type are independent variables. The regression coefficient estimates how the intervention effects of each subgroup differ from the specified reference subgroup. The $p$ value $<0.05$ of each regression coefficient was considered as statistically significant.

\section{Results}

Characteristics of eligible studies on the relation between $\mathrm{HL}$ and QOL

Based on their titles and abstracts, 3274 articles met our criteria. After careful review, 23 studies [11-13, 16-20, 29-43] fulfilled our selection criteria for meta-analysis. The flow chart of this selection procedure is shown in Fig. 1.

The included studies were published between 2005 and February 2018. The detailed information for review is described in Table 1. The design types of these studies included cohort studies and cross-sectional studies. A total of 13 studies were conducted between 1995 and 2015, but 10 studies had no survey time attributed to them. The study subjects were mainly college students, community residents and patients. They were mostly adults, and the majority of them were women. The instruments of measuring QOL were mainly the EuroQol-5 Dimension (EQ-5D) [44], the 12 item short form health questionnaire survey (SF-12), the 36 item short form health questionnaire survey (SF-36) [45] and other self-developed questionnaires, while the instruments of HL were mainly the Test of Functional Health literacy in Adults (TOFHLA) [46], the Rapid Estimate of Adult Literacy in Medicine

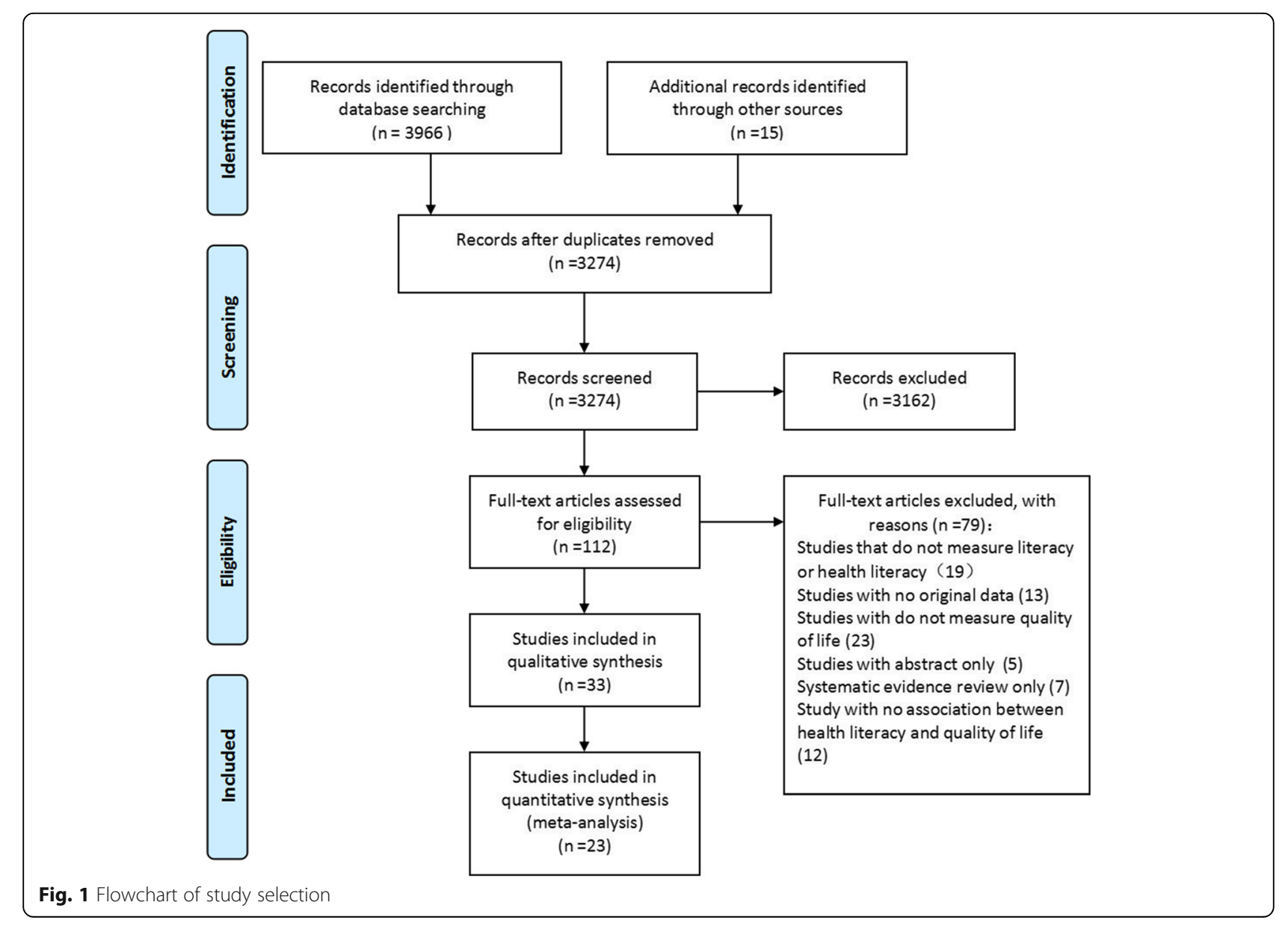


Table 1 Summary of the 23 publications included in the review

\begin{tabular}{|c|c|c|c|c|c|c|c|}
\hline Author & Design & $\begin{array}{l}\text { Survey } \\
\text { time }\end{array}$ & Location & $\begin{array}{l}\text { Study } \\
\text { population }\end{array}$ & $\begin{array}{l}\mathrm{QOL} \\
\text { instrument }\end{array}$ & $\begin{array}{l}\mathrm{HL} \\
\text { instrument }\end{array}$ & $\begin{array}{l}\text { Quality } \\
\text { score }\end{array}$ \\
\hline $\begin{array}{l}\text { Chunhua L, } \\
\text { et al. } 2013 \text { [17] }\end{array}$ & Cross-sectional & April-June, 2012 & Guangzhou,China & $\begin{array}{l}2109 \text { college students } \\
\text { (age: } 15-28 \text { years, } \\
55.2 \% \text { female) }\end{array}$ & EQ-5D & $\begin{array}{l}\text { Self-developed } \\
\text { scales: } \\
\text { Three aspects } \\
\text { of HL, Five } \\
\text { types of HL }\end{array}$ & 9 \\
\hline $\begin{array}{l}\text { Nan W, } \\
\text { et al. } 2012 \text { [18] }\end{array}$ & Cross-sectional & - & Jiaozuo, China & $\begin{array}{l}600 \text { community } \\
\text { elders (age: } \\
\text { over } 45 \text { years, } \\
57.5 \% \text { female) }\end{array}$ & SF-36 & $\begin{array}{l}\text { Questionnaire } \\
\text { on the health } \\
\text { literacy of } \\
\text { Chinese citizens }\end{array}$ & 6 \\
\hline $\begin{array}{l}\text { Liu L, et al. } \\
2016 \text { [19] }\end{array}$ & Cross-sectional & $\begin{array}{l}\text { January-September, } \\
2015\end{array}$ & Urumqi,China & $\begin{array}{l}556 \text { coronary heart } \\
\text { disease patients } \\
\text { (age: } 45-83 \text { years, } \\
31.1 \% \text { female) }\end{array}$ & EQ-5D & $\begin{array}{l}\text { Self-developed } \\
\text { questionnaire } \\
\text { containing } \\
\text { Four dimensions } \\
\text { of HL: knowledge, } \\
\text { attitude, behaviors, } \\
\text { skills. }\end{array}$ & 9 \\
\hline $\begin{array}{l}\text { Yan Z, et al. } \\
2012[43]\end{array}$ & Cross-sectional & - & Jilin, China & $\begin{array}{l}192 \text { empty nest } \\
\text { elders(over } 65 \text { years, } \\
57.8 \% \text { female) }\end{array}$ & SF-36 & $\begin{array}{l}\text { Self-developed } \\
\text { questionnaire } \\
\text { measuring health } \\
\text { literacy of elderly }\end{array}$ & 6 \\
\hline $\begin{array}{l}\text { Qiyuan L, } \\
\text { et al. } 2011 \text { [42] }\end{array}$ & Cross-sectional & $\begin{array}{l}\text { May-November, } \\
2010 .\end{array}$ & Yanji, China & $\begin{array}{l}331 \text { Hypertensive } \\
\text { elderly (over } 60 \text { years, } \\
63.4 \% \text { female) }\end{array}$ & $\begin{array}{l}\text { Self-developed } \\
\text { questionnaire } \\
\text { containing } \\
\text { Global QOL, } \\
\text { Psychological } \\
\text { general well-being, } \\
\text { Symptom bother }\end{array}$ & $\begin{array}{l}\text { Self-developed } \\
\text { questionnaire } \\
\text { measuring health } \\
\text { literacy about } \\
\text { hypertension }\end{array}$ & 9 \\
\hline $\begin{array}{l}\text { Wenning } D_{1} \\
\text { et al. } 2015 \text { [41] }\end{array}$ & Cross-sectional & $\begin{array}{l}\text { November-December, } \\
2014 .\end{array}$ & Kunming, China & $\begin{array}{l}500 \text { college students } \\
\text { (age: } 17-24 \text { years, } \\
56.7 \% \text { female) }\end{array}$ & $\begin{array}{l}\text { Self-developed } \\
\text { questionnaire } \\
\text { measuring QOL } \\
\text { of college students }\end{array}$ & $\begin{array}{l}\text { Self-developed } \\
\text { questionnaire } \\
\text { measuring health } \\
\text { literacy of college } \\
\text { students }\end{array}$ & 8 \\
\hline $\begin{array}{l}\text { Couture EM, } \\
\text { et al. } 2017 \text { [34] }\end{array}$ & Cross-sectional & - & Quebec, Canada & $\begin{array}{l}247 \text { chronic } \\
\text { Participants (age: } \\
18-85 \text { years, } \\
55.5 \% \text { female) }\end{array}$ & SF-12V2 & NVS & 7 \\
\hline $\begin{array}{l}\text { Halverson } J \mathrm{~L}, \\
\text { et al. } 2015 \text { [35] }\end{array}$ & Cross-sectional & 2006s-sect & Wisconsin, America & $\begin{array}{l}1841 \text { Wisconsin } \\
\text { residents, newly } \\
\text { diagnosed with lung, } \\
\text { prostate, breast, or } \\
\text { colorectal cancer } \\
\text { (age: over } 18 \text { years, } \\
50.8 \% \text { female) }\end{array}$ & FACT-G & $\begin{array}{l}\text { Self-developed } \\
\text { questionnaire } \\
\text { containing four } \\
\text { questions } \\
\text { validated in } \\
\text { STOFHLA and } \\
\text { REALM }\end{array}$ & 8 \\
\hline $\begin{array}{l}\text { Naimi AJ, } \\
\text { et al. } 2017 \text { [11] }\end{array}$ & Cross-sectional & - & Tehran, Iran & $\begin{array}{l}400 \text { hypertensive } \\
\text { patients (age: } \\
18-89 \text { years, } \\
45.0 \% \text { female) }\end{array}$ & SF-36 & HELIA & 6 \\
\hline $\begin{array}{l}\text { Song S, et al. } \\
2017 \text { [38] }\end{array}$ & Cross-sectional & $\begin{array}{l}\text { October ectionale } \\
\text { patie }\end{array}$ & South Korea & $\begin{array}{l}305 \text { non-institutionalized } \\
\text { adults (age: } \\
\text { 20-60 years, } \\
50.5 \% \text { female) }\end{array}$ & SF-36 & REALM & 6 \\
\hline $\begin{array}{l}\text { Wang C, et al. } \\
2015 \text { [31] }\end{array}$ & Cross-sectional & - & Northwestern China & $\begin{array}{l}913 \text { poor rural women } \\
\text { (age: } 23-57 \text { ) }\end{array}$ & EQ-5D & R-CAHLQ & 6 \\
\hline $\begin{array}{l}\text { Wang C, et al. } \\
2017 \text { [13] }\end{array}$ & Cross-sectional & $2001 \mathrm{~s}-\mathrm{sec}$ & Six towns, China & $\begin{array}{l}882 \text { hypertensive } \\
\text { patients (age: over } \\
35 \text { years, } 56.1 \% \text { female) }\end{array}$ & SF-36 & $\begin{array}{l}\text { Self-developed } \\
\text { questionnaire } \\
\text { validated } \\
\text { three-item BHLS }\end{array}$ & 7 \\
\hline $\begin{array}{l}\text { Rocha PC, et al. } \\
2017 \text { [37] }\end{array}$ & Cross-sectional & - & Belo Horizonte,Brazil & $\begin{array}{l}384 \text { adolescents } \\
\text { (age: } 15 \text { and } 19 \text { years, } \\
70.3 \% \text { female). }\end{array}$ & PedsQL & $\begin{array}{l}\text { Self-developed } \\
\text { questionnaire, } \\
\text { composed of } \\
\text { closed questions }\end{array}$ & 5 \\
\hline $\begin{array}{l}\text { Macabasco OA, } \\
\text { et al. } 2011 \text { [30] }\end{array}$ & Cross-sectional & $2007-2009$ & America & $\begin{array}{l}605 \text { patients with } \\
\text { symptomatic heart } \\
\text { failure (age: over }\end{array}$ & HFSS & TOFHLA & 7 \\
\hline
\end{tabular}


Table 1 Summary of the 23 publications included in the review (Continued)

\begin{tabular}{|c|c|c|c|c|c|c|c|}
\hline Author & Design & $\begin{array}{l}\text { Survey } \\
\text { time }\end{array}$ & Location & $\begin{array}{l}\text { Study } \\
\text { population }\end{array}$ & $\begin{array}{l}\mathrm{QOL} \\
\text { instrument }\end{array}$ & $\begin{array}{l}\mathrm{HL} \\
\text { instrument }\end{array}$ & $\begin{array}{l}\text { Quality } \\
\text { score }\end{array}$ \\
\hline & & & & 18 years, $48.0 \%$ female) & & & \\
\hline $\begin{array}{l}\text { Johnston MV, } \\
\text { et al. } 2005 \text { [36] }\end{array}$ & Cross-sectional & - & new jersey,America & $\begin{array}{l}107 \text { patients with spinal } \\
\text { cord injury (age: over } \\
18 \text { years, } 17.8 \% \text { female) }\end{array}$ & SF-12,SWLS & TOFHLA & 6 \\
\hline $\begin{array}{l}\text { Ownby RL, } \\
\text { et al. } 2014 \text { [12] }\end{array}$ & Cross-sectional & - & $\begin{array}{l}\text { Central and South } \\
\text { America as well as } \\
\text { Mexico and the US }\end{array}$ & $\begin{array}{l}475 \text { English- and Spanish- } \\
\text { speaking community- } \\
\text { dwelling volunteers(age: } \\
18-81 \text { years, } 60 \% \text { female) }\end{array}$ & SF-36,EQ-5D & TOFHLA, REALM & 5 \\
\hline $\begin{array}{l}\text { Zhang XH, } \\
\text { et al. } 2009 \text { [40] }\end{array}$ & Cross-sectional & - & $\begin{array}{l}\text { a tertiary referral } \\
\text { center,Singapore }\end{array}$ & $\begin{array}{l}199 \text { patients with } \\
\text { rheumatic diseases (over } \\
18 \text { years, } 70.5 \% \text { female) }\end{array}$ & $\begin{array}{l}\text { SF-36,EQ-5D, } \\
\text { and SF-6D. }\end{array}$ & REALM & 6 \\
\hline $\begin{array}{l}\text { Wallace LS, } \\
\text { et al. } 2008 \text { [39] }\end{array}$ & Cross-sectional & September, 2004 & Tennesseans,America & $\begin{array}{l}249 \text { patients (age: over } \\
18 \text { years, } 65.1 \% \text { female) }\end{array}$ & $\begin{array}{l}\text { Self-developed: } \\
\text { fouritems } \\
\text { developed and } \\
\text { validated by CDC }\end{array}$ & REALM & 8 \\
\hline $\begin{array}{l}\text { Son YJ, et al. } \\
2016[32]\end{array}$ & $\begin{array}{l}\text { Longitudinal } \\
\text { cohort }\end{array}$ & June 2012-July 2013 & Cheonan,Korean & $\begin{array}{l}238 \mathrm{PCl} \text { patients } \\
\text { (33.2\% female) }\end{array}$ & $\begin{array}{l}\text { Self-developed: } \\
\text { a validating 10- } \\
\text { item questionnaire }\end{array}$ & $\begin{array}{l}\text { Self-developed } \\
\text { containing the } \\
\text { three-item set of } \\
\text { brief screening } \\
\text { questions }\end{array}$ & 9 \\
\hline $\begin{array}{l}\text { Mancuso CA, } \\
\text { et al. } 2006 \text { [33] }\end{array}$ & $\begin{array}{l}\text { Longitudinal } \\
\text { cohort }\end{array}$ & 1995-1999 & New York,America & $\begin{array}{l}175 \text { asthma patients } \\
\text { (mean age: } 40 \text { years, } \\
83 \% \text { female) }\end{array}$ & AQLQ & TOFHLA & 9 \\
\hline $\begin{array}{l}\text { Al SF, et al. } \\
2016 \text { [29] }\end{array}$ & $\begin{array}{l}\text { Longitudinal } \\
\text { cohort }\end{array}$ & $\begin{array}{l}\text { December } 2011- \\
\text { December } 2013\end{array}$ & Alberta,Canada & $\begin{array}{l}1948 \text { Patients with type } \\
2 \text { diabetes (age: over } \\
18 \text { years, } 45.0 \% \text { female) }\end{array}$ & EQ-5D,SF-36 & BHLS & 7 \\
\hline $\begin{array}{l}\text { Montbleau KE, } \\
\text { et al. } 2017 \text { [10] }\end{array}$ & Cohort & - & $\begin{array}{l}\text { an urban, safety-net } \\
\text { hospital,America }\end{array}$ & $\begin{array}{l}40 \text { patients with Atrial } \\
\text { fibrillation (age: Over } \\
60 \text { years, } 45.0 \% \text { female) }\end{array}$ & SF-36 & STOFHLA & 6 \\
\hline $\begin{array}{l}\text { Husson } \mathrm{O}_{1} \\
\text { et al. } 2015 \text { [20] }\end{array}$ & Longitudinal & $2000-2009$ & $\begin{array}{l}\text { southern part of } \\
\text { the Netherlands }\end{array}$ & $\begin{array}{l}1626 \text { Colorectal cancer } \\
\text { survivors (age: over } \\
18 \text { years, } 42.9 \% \text { female) }\end{array}$ & EORTC QLQ-C30 & SBSQ & 9 \\
\hline
\end{tabular}

EQ-5D the European Quality of Life-5 Dimensions, SF-36 the 36-item Short Form, SF-12v2 Short Form Health Survey, NVS the Newest Vital Sign, FACT-G the Functional Assessment of Cancer Therapy-General, STOFHLA Short Test of Functional Health Literacy in Adults, REALM the Rapid Estimate of Adult Literacy in Medicine, HELIA Health Literacy for Iranian Adults, R-CAHLQ the revised Chinese Adult Health Literacy Questionnaire, BHLS Brief Health Literacy Screening, PedsQL the Paediatric Questionnaire on Quality of Life, HFSS the Heart Failure Symptom Scale, TOFHLA Test of Functional Health Literacy in Adults, SWLS Satisfaction with Life Scale, AQLQ the Asthma Quality of Life Questionnaire, SBSQ Chew's three-item Set of Brief Screening Questions, EORTC QLQ-C30 Research and Treatment of Cancer Quality of Life Questionnaire C30

(REALM) [47], the Newcastle-Ottawa Scale (NVS) [48], and self-developed questionnaires. The details are shown in Table 1.

\section{Methodological quality}

NOS was used to score 4 of the cohort studies, and 19 of the cross-sectional studies were scored using the AHRQ. Of the studies scored by NOS, the minimum score was 7 , the maximum score was 9 , and the average score was 8.5 . Of the studies scored by AHRQ, the minimum score was 5 , the maximum score was 9 , and the average was 6.89 (Table 1).

\section{The correlation between $\mathrm{HL}$ and QOL}

\section{General correlation}

A total of 19 studies were included in the analysis of the correlation between HL and QOL, and the total sample size was 12,303 . In the heterogeneity test: the correlation between HL and QOL $\left(I^{2}=97 \%, p<0.001\right)$ showed that there was heterogeneity. The correlation coefficient between QOL and HL was 0. 35 (95\% CI: 0.25-0.44) (Fig. 2).

The correlation between $\mathrm{HL}$ and two dimensions of QOL

The QOL included physical and mental scores. A total of 8 studies were included in the analysis of the correlation between HL and physical QOL, and the total sample size was 5777 . In the heterogeneity test, the correlation between $\mathrm{HL}$ and physical QOL $\left(I^{2}=94 \%\right.$, $p<0.001)$ showed that there was heterogeneity, using a random effect model to combine effect quantity. The correlation coefficient between physical QOL and HL was 0. 20 (95\% CI: 0.08-0.31) (Fig. 2).

In addition, a total of 7 studies were included in the analysis of the correlation between HL and mental QOL, and the total sample size was 5602. In the heterogeneity test, the correlation between $\mathrm{HL}$ and mental QOL $\left(I^{2}=95 \%\right.$, 


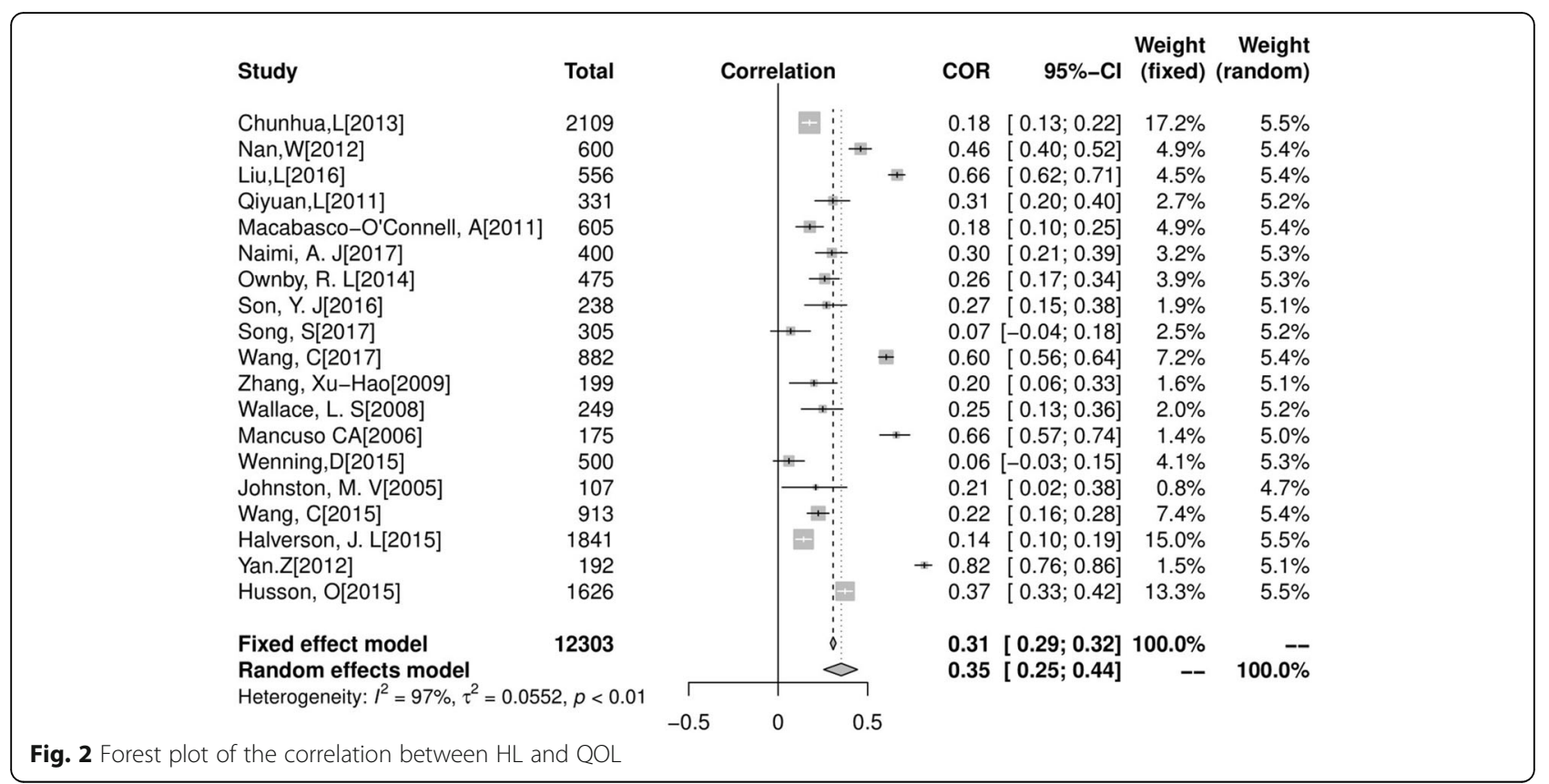

$p<0.001)$ showed that there was heterogeneity, using a random effect model to combine effect quantity. The correlation coefficient between mental QOL and HL was 0. 18 (95\% CI: 0.08-0.31).

The correlation between QOL and four dimensions of $\mathrm{HL}$ HL incorporates health knowledge, health behavior, health belief and health skill. A total of 3 studies were included in the analysis of the correlation between QOL and four dimensions of HL, and the total sample size was 3256 . In the heterogeneity test, the correlation between health knowledge of $\mathrm{HL}$ and QOL $\left(I^{2}=99 \%\right.$, $p<0.001)$ showed that there was heterogeneity. The correlation coefficient between QOL and health knowledge was 0.36 (95\% CI: 0.04-0.61). In the heterogeneity test, the correlation between health behavior of $\mathrm{HL}$ and QOL $\left(I^{2}=97 \%, P<0.001\right)$ showed that there was heterogeneity, using a random effect model to combine effect quantity. The correlation coefficient between QOL and health behavior was 0.36 (95\% CI: 0.13-0.55). In the heterogeneity test, the correlation between health belief of HL and QOL $\left(I^{2}=98 \%, p<0.001\right)$ showed that there was heterogeneity. The correlation coefficient between QOL and health belief was 0.39 ( $95 \%$ CI: $0.10-0.62$ ). In the heterogeneity test, the correlation between health skill of $\mathrm{HL}$ and QOL $\left(I^{2}=99 \%, p<0.001\right)$ showed that there was heterogeneity. The correlation coefficient between QOL and health skill was 0.42 (95\% CI: 0.03-0.69).

\section{Subgroup analysis}

The subgroup analysis included population, time, study design, area, study quality and the kinds of HL instruments and QOL instruments used (Table 2). Noticeably, the correlation coefficient between HL and QOL was 0.46 (95\%CI: $0.13,0.69)$ among community residents, 0.45 (95\%CI: 0.27 , 0.61 ) in China, and 0.45 (95\%CI: 0.24, 0.62) based on cohort study design. The correlation coefficient between HL and QOL on TOFHLA was higher than REALM.

\section{Publication bias}

Funnel plot asymmetry was observed in the studies of correlation between HL and QOL (Fig. 3). Egger's test $(t=1.197, p=0.248)$ indicated that there was no obvious publication bias (Fig. 4).

\section{Sensitivity and meta-regression analysis}

Sensitivity analyses were used to evaluate the effect of each study on the pooled results by sequentially excluding single studies. It was found that the results had no significant change after excluding each study (Additional file 2: Table S2). Meta-regression analysis was used to detect heterogeneity (Table 3). The results showed that cohort study design, studies conducted in China and publication before 2012 may be important influencing factors.

\section{Discussion}

With the development of medical technology and the increase of life expectancy, people pay more attention to their QOL. Health managers and researchers are more concerned about whether improvements in health literacy increase people's QOL. Song, S. [38] showed HL was not positively correlated with QOL, and the correlation coefficient between HL and QOL was only 0.07. However, Liu, L [19] showed that the correlation coefficient 
Table 2 Subgroup analysis of the correlation between $\mathrm{HL}$ and QOL

\begin{tabular}{|c|c|c|c|c|}
\hline Subgroup & $\begin{array}{l}\text { Sample } \\
\text { size }\end{array}$ & $\begin{array}{l}\text { No. of } \\
\text { studies }\end{array}$ & $\begin{array}{l}\text { correlation coefficient } \\
{[95 \% \mathrm{Cl}]}\end{array}$ & $P$ \\
\hline Total & 12,303 & 19 & $0.35[0.25 ; 0.44]$ & $<0.01$ \\
\hline \multicolumn{5}{|l|}{ Populationl } \\
\hline College students & 2609 & 2 & $0.12[0.01 ; 0.23]$ & 0.02 \\
\hline $\begin{array}{l}\text { Community } \\
\text { residents }\end{array}$ & 1572 & 4 & $0.46[0.13 ; 0.69]$ & $<0.01$ \\
\hline \multicolumn{5}{|l|}{ Populationll } \\
\hline Patients & 8122 & 13 & $0.35[0.25 ; 0.44]$ & $<0.01$ \\
\hline Health & 4181 & 6 & $0.35[0.14 ; 0.53]$ & $<0.01$ \\
\hline \multicolumn{5}{|l|}{ Nation } \\
\hline China & 6083 & 8 & $0.45[0.27 ; 0.61]$ & $<0.01$ \\
\hline America & 3452 & 6 & $0.29[0.16 ; 0.42]$ & $<0.01$ \\
\hline $\begin{array}{l}\text { Other Asian } \\
\text { countries }\end{array}$ & 1142 & 4 & $0.21[0.10 ; 0.32]$ & 0.01 \\
\hline \multicolumn{5}{|l|}{$\mathrm{HL}$ questionnaire } \\
\hline REALM & 753 & 3 & $0.17[0.06 ; 0.28]$ & 0.08 \\
\hline TOFHLA & 1362 & 4 & $0.35[0.12 ; 0.54]$ & $<0.01$ \\
\hline Other instruments & 10,188 & 12 & $0.39[0.27 ; 0.51]$ & $<0.01$ \\
\hline \multicolumn{5}{|l|}{ QOL questionnaire } \\
\hline EQ-5D & 2665 & 2 & $0.45[0 ; 0.80]$ & $<0.01$ \\
\hline SF & 4073 & 9 & $0.38[0.22 ; 0.53]$ & $<0.01$ \\
\hline Other instruments & 5565 & 8 & $0.29[0.17 ; 0.39]$ & $<0.01$ \\
\hline \multicolumn{5}{|l|}{ Study design } \\
\hline Cross-sectional & 10,264 & 16 & $0.33[0.22 ; 0.44]$ & $<0.01$ \\
\hline Cohort & 2039 & 3 & $0.45[0.24 ; 0.62]$ & $<0.01$ \\
\hline \multicolumn{5}{|l|}{ Study quality } \\
\hline High & 7625 & 9 & $0.34[0.20 ; 0.46]$ & $<0.01$ \\
\hline Medium & 4678 & 10 & $0.36[0.21 ; 0.50]$ & $<0.01$ \\
\hline Low & 0 & 0 & & \\
\hline \multicolumn{5}{|l|}{ Time } \\
\hline Before 2012.01 & 5709 & 7 & $0.37[0.21 ; 0.51]$ & $<0.01$ \\
\hline After 2012.01 & 3708 & 5 & $0.27[0.01 ; 0.49]$ & $<0.01$ \\
\hline No found & 2886 & 7 & $0.39[0.21 ; 0.54]$ & $<0.01$ \\
\hline
\end{tabular}

between $\mathrm{HL}$ and QOL among patients with coronary heart disease was 0.665 . This study showed the HL had a moderate positive correlation with QOL $(r=0.35, p<0.05)$ through meta-analysis, which is helpful for further research. It suggested that people with low HL may pay low attention to their health status and therefore they had unhealthy behavior habits that caused a decline of QOL [49]. This study also analyzes the interaction relations between dimensions of $\mathrm{HL}$ and dimensions of QOL. The correlation between $\mathrm{HL}$ and the two dimensions of QOL was lower than the total correlation coefficient of overall $\mathrm{HL}$ and QOL. The correlation between QOL and the four dimensions of $\mathrm{HL}$

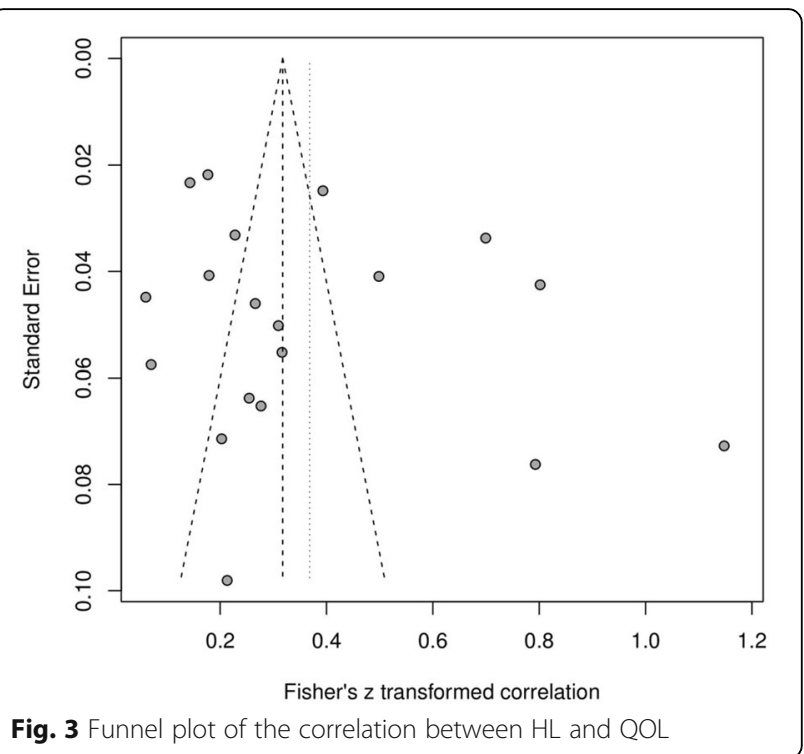

was higher than the total correlation coefficient of overall HL and QOL, among which the correlation between health skills and QOL was highest. Health skill refers to the ability of individuals to transform health knowledge into healthy behaviors. It plays an intermediary role between health knowledge and health behavior. Good health skills improve health status and QOL. Mental health conditions closely related to the quality of the individual's life will also improve health skills. Some studies divided the QOL into two dimensions [29, 34, 36], while other studies divided it into more than two dimensions $[20,50]$. However, after HL and QOL were divided into different dimensions, fewer studies were included as they may not be general and reliable correlation coefficients.

In subgroup analysis, population, time, study design, study quality, area, and the type of HL instruments and QOL instruments were analyzed. Among the population subgroup, the college students' correlation coefficient between HL and QOL was lower, it may be that the overall health literacy of college students is similar, but the difference in quality of life scores is more related to the psychological status of students such as anxiety and depression. In addition, the patients' correlation coefficient was higher than that of the healthy population, indicating that patients who had higher health knowledge had relatively low requirements for QOL. In terms of study design, the cohort study's correlation coefficient between HL and QOL was higher than cross-sectional study's correlation due to the study design. In terms of region, the correlation coefficient of studies conducted in China was the highest, followed by American region and other regions of Asia. The reason may be that the sample size of China was 6083: higher than the United States (3452) and other parts of Asia (1142). For the instruments, 


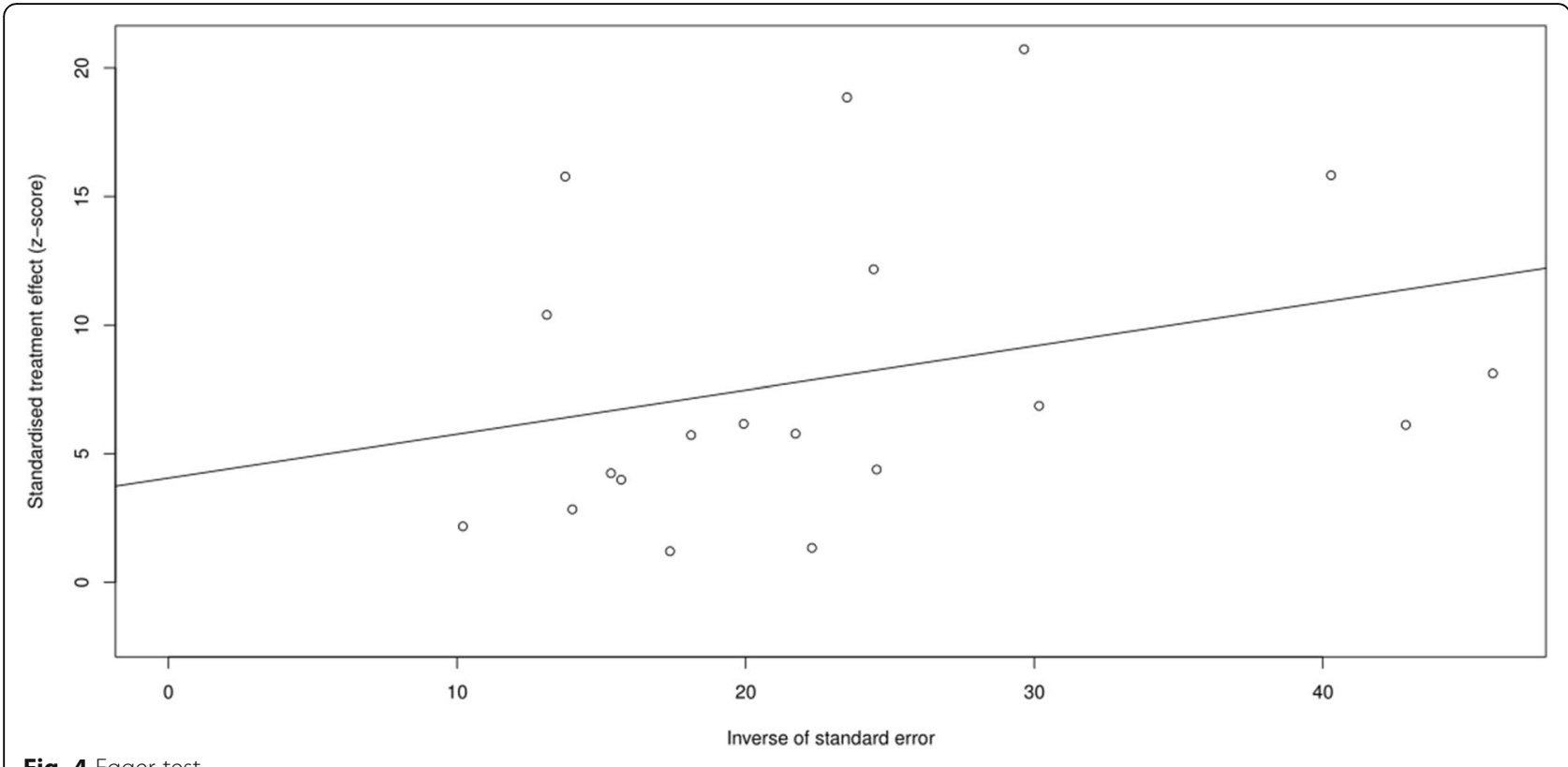

Fig. 4 Egger test

TOFHLA for the HL questionnaire and the short form questionnaire for the QOL questionnaire were better than others. Similar to the result of subgroup analysis, meta-regression analysis also showed that cohort study design, studies conducted in China, and publication before 2012 may be important influencing factors.

This study has some limitations. The first limitation is in the study design used. Mainly cross-sectional studies were included, which collected HL and QOL at the same time and never reflected on the long-term impact of lower HL on QOL. This is why the cohort study's correlation coefficient between HL and QOL was higher than cross-sectional study's correlation, and the insufficiency is that there are fewer studies included in the cohort study. The second limitation is with regard to the quality of the data collected. The data of studies included $\beta$ and

Table 3 Meta regression on correlation coefficient

\begin{tabular}{|c|c|c|c|c|}
\hline Variables & & Estimate & $95 \% \mathrm{Cl}$ & $P$-value \\
\hline Intercept & & 0.93 & {$\left[\begin{array}{ll}0.37 & 1.49\end{array}\right]$} & 0.001 \\
\hline Sample size & & -0.00 & {$[-0.00-0.00]$} & 0.000 \\
\hline \multirow[t]{2}{*}{ Design } & Cross-sectional & ref & & \\
\hline & Cohort & 0.47 & {$\left[\begin{array}{ll}0.11 & 0.83\end{array}\right]$} & 0.011 \\
\hline \multirow[t]{3}{*}{ Area } & America & Ref & & \\
\hline & China & 0.37 & {$\left[\begin{array}{lll}0.06 & 0.69\end{array}\right]$} & 0.021 \\
\hline & Asia other country & 0.26 & {$\left[\begin{array}{ll}-0.18 & 0.72]\end{array}\right]$} & 0.246 \\
\hline \multirow[t]{2}{*}{ Population } & Health & ref & & \\
\hline & Patient & -0.25 & {$\left[\begin{array}{ll}-0.55 & 0.05\end{array}\right]$} & 0.097 \\
\hline \multirow[t]{2}{*}{ HL questionnaires } & TOFHLA & ref & & \\
\hline & REALM & -0.41 & {$\left[\begin{array}{ll}-0.85 & 0.02\end{array}\right]$} & 0.059 \\
\hline \multirow[t]{2}{*}{ QOL questionnaires } & EQ-5D & ref & & \\
\hline & SF & -0.74 & {$\left[\begin{array}{lll}-1.50 & 0.01\end{array}\right]$} & 0.053 \\
\hline \multirow[t]{2}{*}{ Study quality } & High & ref & & \\
\hline & medium & 0.22 & {$\left[\begin{array}{lll}-0.34 & 0.77\end{array}\right]$} & 0.443 \\
\hline \multirow[t]{2}{*}{ Time } & After 2012 & ref & & \\
\hline & Before 2012 & 0.61 & {$[0.12$ 1.09] } & 0.014 \\
\hline
\end{tabular}


$r$ and rank correlation r. Some studies [21, 31, 50, 51] showed that compared poor and medium HL with high HL showed that $\beta$ was not the general value between HL and QOL. As a result, this part of the value was not included in the meta-analysis. The third limitation is with regard to the questionnaire used. The questionnaires for HL and QOL were not unified, which increased the heterogeneity of the meta-analysis and the subsequent possibility of bias in the results. Therefore, studies with larger sample sizes and better data quality are needed to further confirm the finding. In addition, the heterogeneity of the subjects, the different ages and health conditions are influencing factors on the results.

\section{Conclusion}

In summary, HL was moderately correlated with QOL, and the correlation coefficient between QOL and health knowledge, health behavior, health belief, and health skill were statistically significant. However, these findings need to be supported by more evidence.

\section{Additional files}

Additional file 1: Table S1. PRISMA checklist. (DOC $61 \mathrm{~kb}$ )

Additional file 2: Table S2. Sensitivity analysis of Meta. (DOCX 15 kb)

\section{Abbreviations}

AHRQ: Agency for Healthcare Research and Quality; Cl: Confidence Interval; CNKI: China National Knowledge Infrastructure; EQ-5D: The European Quality of Life-5 Dimensions; HL: Health Literacy; MeSH: Medical subject headings; NOS: The Newcastle-Ottawa Scale; NVS: The Newest Vital Sign; PCOR: The pooled correlation coefficient; QOL: Quality of Life; REALM: The Rapid Estimate of Adult Literacy in Medicine; SF-12: The 12-item Short Form; SF-36: The 36-item Short Form; TOFHLA: Test of Functional Health Literacy in Adults

\section{Acknowledgements}

The authors would like to like to thank School of Public Health, of Southeast University and Jiangsu Provincial Center for Disease Control and Prevention for providing resources and support.

\section{Funding}

This study was supported in part by Chinese National Natural Fund (81573258) and by the Social Development Fund of Jiangsu Province (SBE2017710 and SBE2015714).

\section{Availability of data and materials}

EMBASE, PubMed, Web of Science, Elsevier, Cochrane Library, and Chinese electronic databases.

\section{Authors' contributions}

MZ participated in the data analysis and drafted the manuscript. HJ participated in the conception and design of the study. All authors contributed to interpretation of findings and approving the manuscript.

\section{Ethics approval and consent to participate} Not applicable.

\section{Consent for publication}

Not applicable.

\section{Competing interests}

The authors declare that they have no competing interests.

\section{Publisher's Note}

Springer Nature remains neutral with regard to jurisdictional claims in published maps and institutional affiliations.

\section{Author details}

'Department of Epidemiology and Health Statistics, School of Public Health, Southeast University, Nanjing 210009, China. ${ }^{2}$ Key Laboratory of

Environmental Medicine Engineering, Ministry of Education, School of Public Health, Southeast University, Nanjing 210009, China. ${ }^{3}$ Jiangsu Provincial Center for Disease Control and Prevention, Nanjing 210009, China.

Received: 13 May 2018 Accepted: 8 October 2018

Published online: 16 October 2018

\section{References}

1. Wang HM, Beyer M, Gensichen J, Gerlach FM. Health-related quality of life among general practice patients with differing chronic diseases in Germany: cross sectional survey. BMC Public Health. 2008;8:246.

2. Miguel RS, Lopez-Gonzalez AM, Sanchez-Iriso E, Mar J, Cabases JM. Measuring health-related quality of life in drug clinical trials: is it given due importance? Pharm World Sci. 2008;30(2):154-60.

3. Jiqian F, Chonghua W, Yuantao H, Mingli S, Fengqiong Z, Fengbin L. Research and application of health related quality of life. Statistics Forecasts. 2001;01:26-8.

4. Sorensen K, Van den Broucke S, Fullam J, Doyle G, Pelikan J, Slonska Z, et al. Health literacy and public health: a systematic review and integration of definitions and models. BMC Public Health. 2012;12:80.

5. Sorensen K, Pelikan JM, Rothlin F, Ganahl K, Slonska Z, Doyle G, et al. Health literacy in Europe: comparative results of the European health literacy survey (HLS-EU). Eur J Pub Health. 2015;25(6):1053-8.

6. Visscher KL, Hutnik CM. Reprint of: health literacy in Canada and the ophthalmology patient. Canadian journal of ophthalmology journal canadien d. Ophtalmologie. 2015;50(1):S40-6.

7. Adams RJ, Appleton SL, Hill CL, Dodd M, Findlay C, Wilson DH. Risks associated with low functional health literacy in an Australian population. Med J Aust. 2009;191(10):530-4

8. Mark K, Elizabeth G, Ying J, al e. The health literacy of America's adults: results from the 2003 National Assessment of adult literacy. Washington: National Center for education. Statistics. 2006;39(10):685-87.

9. Hongwen Y, Qi S, Yinghua L. Present situation and countermeasure of health literacy of urban and rural residents in China. Popul Stud. 2016;02:88-97.

10. Montbleau KE, King D, Henault L, Magnani JW. Health literacy, health-related quality of life, and atrial fbrillation. Cogent Med. 2017;4:1412121.

11. Naimi AJ, Naderiravesh N, Bayat ZS, Shakeri N, Matbouei M. Correlation between health literacy and health-related quality of life in patients with hypertension, in Tehran, Iran, 2015-2016. Electron Physician. 2017;9(11): 5712-20.

12. Ownby RL, Acevedo A, Jacobs RJ, Caballero J, Waldrop-Valverde D. Quality of life, health status, and health service utilization related to a new measure of health literacy: FLIGHTNIDAS. Patient Educ Couns. 2014;96(3):404-10.

13. Wang C, Lang J, Xuan L, Li X, Zhang L. The effect of health literacy and selfmanagement efficacy on the health-related quality of life of hypertensive patients in a western rural area of China: a cross-sectional study. Int J Equity Health. 2017;16(1):58.

14. Yehle KS, Plake KS, Nguyen P, Smith D. Health-related quality of life in heart failure patients with varying levels of health literacy receiving telemedicine and standardized education. Home Healthc Now. 2016;34(5):267-72.

15. Shi D, Li J, Wang Y, Wang S, Liu K, Shi R, et al. Association between health literacy and hypertension management in a Chinese community: a retrospective cohort study. Intern Emerg Med. 2017;12(6):765-76.

16. Lee EH, Lee YW, Moon SH. A structural equation model linking health literacy to self-efficacy, self-care activities, and health-related quality of life in patients with type 2 diabetes. Asian Nurs Res. 2016;10(1):82-7.

17. Luo C. Study on the current situation and influencing factors of health literacy of some college students in Guangzhou [D]. Shandong: Jinan University; 2013

18. Wang $N$. The influence of self-efficacy on health literacy and quality of life of the elderly in community [D]. Hunan: Nanhua University; 2012.

19. Liu L. Study on the correlation between health literacy and quality of life and direct medical cost of middle-aged and elderly inpatients with coronary[D]. Xinjiang Medical University; 2016. 
20. Husson O, Mols F, Fransen MP, van de Poll-Franse LV, Ezendam NPM. Low subjective health literacy is associated with adverse health behaviors and worse health-related quality of life among colorectal cancer survivors: results from the profiles registry. Psycho-Oncology. 2015;24(4):478-86.

21. Curtis $L M$, Wolf MS, Weiss KB, Grammer LC. The impact of health literacy and socioeconomic status on asthma disparities. J Asthma. 2012:49(2):178-83.

22. Jayasinghe UW, Harris MF, Parker SM, Litt J, van Driel M, Mazza D, et al. The impact of health literacy and life style risk factors on health-related quality of life of Australian patients. Health Qual Life Outcomes. 2016;14:68.

23. Moher D, Liberati A, Tetzlaff J, Altman DG, Grp P. Preferred reporting items for systematic reviews and Meta-analyses: the PRISMA statement. PLoS Med. 2009;18(3):e123.

24. Wells G, Shea B, O'Connell D, Peterson J, Welch V, Losos M, et al. The Newcastle-Ottawa scale (NOS) for assessing the quality of nonrandomised studies in meta-analyses. 2013.

25. DM, D, GG, S, DM, D, al, e. Agency for Healthcare Research and Quality: International Conference of the IEEE Engineering in Medicine \& Biology Society 2008.

26. Cacciamani GE, Medina LG, Gill T, Abreu A, Sotelo R, Artibani W, et al. Impact of surgical factors on robotic partial nephrectomy outcomes: comprehensive systematic review and Meta-analysis. J Urol. 2018;200(2):258-74.

27. Dougherty DM, Shapiro GG, Dougherty DM, Shapiro GG, editors. Agency for Healthcare Research and Quality. International conference of the IEEE engineering in Medicine \& Biology Society; 2002.

28. Juming D. Research on data conversion method in Meta analysis[D]. Guangdong: Southern medical university; 2014.

29. Al Sayah F, Qiu W, Johnson JA. Health literacy and health-related quality of life in adults with type 2 diabetes: a longitudinal study. Qual Life Res. 2016; 25(6):1487-94.

30. Macabasco-O'Connell A, DeWalt DA, Broucksou KA, Hawk V, Baker DW, Schillinger D, et al. Relationship between literacy, knowledge, self-care behaviors, and heart failure-related quality of life among patients with heart failure. J Gen Intern Med. 2011;26(9):979-86.

31. Wang C, Kane RL, Xu D, Meng Q. Health literacy as a moderator of healthrelated quality of life responses to chronic disease among Chinese rural women. BMC Womens Health. 2015:15:34.

32. Son YJ, Yu HY. Influence of health literacy on HRQoL in patients after PCl. West J Nurs Res. 2016:38(12):1611-26.

33. Mancuso CA, Rincon M. Impact of health literacy on longitudinal asthma outcomes. J Gen Intern Med. 2006;21(8):813-7.

34. Couture EM, Chouinard M-C, Fortin M, Hudon C. The relationship between health literacy and quality of life among frequent users of health care services: a cross-sectional study. Health Qual Life Outcomes. 2017;15:137.

35. Halverson $J$, Martinez-Donate AP, Palta M, Leal T, Lubner S, Walsh MC, et al. Health literacy and health-related quality of life among a population-based sample of Cancer patients. J Health Commun. 2015;20(11):1320-9.

36. Johnston MV, Diab ME, Kim SS, Kirshblum S. Health literacy, morbidity, and quality of life among individuals with spinal cord injury. J Spinal Cord Med. 2005;28(3):230-40

37. Rocha PC, Rocha DC, Lemos SMA. Functional health literacy and quality of life of high-school adolescents in state schools in Belo Horizonte. CoDAS. 2017;29(4):e20160208.

38. Song S, Lee SM, Jang S, Lee YJ, Kim NH, Sohn HR, et al. Mediation effects of medication information processing and adherence on association between health literacy and quality of. Life. 2017;17(1):661.

39. Wallace LS, Rogers ES, Weiss BD. Relationship between health literacy and health-related quality of life among Tennesseans. Tenn Med. 2008;101(5):35-9.

40. Zhang XH, Li SC, Fong KY, Thumboo J. The impact of health literacy on health-related quality of life (HRQOL) and utility assessment among patients with rheumatic diseases. Value Health. 2009;12:S106-S9.

41. Duan W. Investigation and analysis of health literacy status of college students in Kunming city [D]. Yunnan: Yunnan University; 2015.

42. Lv Q. Study on the relationship between health literacy, drug treatment compliance and quality of life of elderly hypertension patients in yanbian han nationality. 2011

43. Zhao Y, Gao L. Logistic regression analysis of health literacy of emptynesters in community on influencing factors of quality of life. Chinese Foreign Med Res. 2012;10(15):57-8.

44. Herdman M, Gudex C, Lloyd A, Janssen MF, Kind P, Parkin D, et al. Development and preliminary testing of the new five-level version of EQ-5D (EQ-5D-5L). Qual Life Res. 2011;20(10):1727-36.
45. Optum Inc. 2018. Available from: https://campaign.optum.com/content/ optum/en/optum-outcomes/what-we-do/health-surveys.html.

46. Parker RM, Baker DW, Williams MV, Nurss JR. The test of functional health literacy in adults. J Gen Intern Med. 1995:10(10):537-41.

47. Davis TC, Crouch MA, Long SW, Jackson RH, Bates P, George RB, et al. Rapid assessment of literacy levels of adult primary care patients. Fam Med. 1991; 23(6):433-5

48. Weiss BD, Mays MZ, Martz W, Castro KM, DeWalt DA, Pignone MP, et al. Quick assessment of literacy in primary care: the newest vital sign. Ann Fam Med. 2005;3(6):514-22.

49. Berkman ND, Sheridan SL, Donahue KE, Halpern DJ, Crotty K. Low health literacy and health outcomes: an updated systematic review. Ann Intern Med. 2011;155(2):97-107.

50. Panagioti M, Skevington SM, Hann M, Howells K, Blakemore A, Reeves D, et al. Effect of health literacy on the quality of life of older patients with longterm conditions: a large cohort study in UK general practice. Qual Life Res. 2018;27(5):1257-68.

51. Song L, Mishel M, Bensen JT, Chen RC, Knafl GJ, Blackard B, et al. How does health literacy affect quality of life among men with newly diagnosed clinically localized prostate cancer? Cancer. 2012;118(15):3842-51.
Ready to submit your research? Choose BMC and benefit from:

- fast, convenient online submission

- thorough peer review by experienced researchers in your field

- rapid publication on acceptance

- support for research data, including large and complex data types

- gold Open Access which fosters wider collaboration and increased citations

- maximum visibility for your research: over $100 \mathrm{M}$ website views per year

At BMC, research is always in progress.

Learn more biomedcentral.com/submissions 